\title{
Characterization of Methanobrevibacter arboriphilicus SA Isolated from a Paddy Field Soil and DNA-DNA Hybridization among $M$. arboriphilicus strains
}

\author{
SUSUMU ASAKAWA, ${ }^{1 *}$ HIROYUKI MORII, ${ }^{2}$ MASAYO AKAGAWA-MATSUSHITA, ${ }^{2}$ \\ YOSUKE KOGA, ${ }^{2}$ AND KOICHI HAYANO ${ }^{1}$ \\ Laboratory of Soil Microbiology, Kyushu National Agricultural Experiment Station, Nishigoshi, \\ Kumamoto $861-11,{ }^{1}$ and Department of Chemistry, University of Occupational \\ and Environmental Health, Japan, Kitakyushu 807,2 Japan
}

\begin{abstract}
We isolated a methanogenic strain, designated strain SA (= DSM 7056), from an enrichment culture inoculated with a Japanese paddy field soil. Cells of this strain were strictly anaerobic, nonmotile, short rods and stained gram positive. The strain was able to use $\mathrm{H}_{2}-\mathrm{CO}_{2}$ or formate as a methanogenic substrate. It required vitamins, but not acetate, for growth. Growth was fastest at 35 to $40^{\circ} \mathrm{C}$. Methane was produced most rapidly at pH 6.0 to 7.5. The cellular lipid composition of strain SA was similar to that of $M$. arboriphilicus A2 (= DSM 2462). The $G+C$ content of the DNA was 26.4 mol\%. Strain SA had DNA-DNA hybridization values of more than $70 \%$ with $M$. arboriphilicus DH1 $^{\mathrm{T}}$ (= DSM $1125^{\mathrm{T}}$ ). On the basis of phenotypic and genotypic characteristics, we identified strain SA as $M$. arboriphilicus. In the course of our identification work, the genetic heterogeneity of $M$. arboriphilicus was revealed by the results of DNA-DNA hybridization experiments. Although strain AZ (= DSM 744) should be classified as a member of a species distinct from the species containing the other four strains studied $\left(\mathrm{DH}^{\mathrm{T}}, \mathrm{A2}\right.$, DC [= DSM 1536], and SA), further phenotypic characterization will be required before a new species can be proposed.
\end{abstract}

Methane is one of the greenhouse gases, and paddy fields are reported to be an important source of atmospheric $\mathrm{CH}_{4}$ (4). Rajagopal et al. isolated and characterized two Methanobacterium-like strains and two Methanosarcina-like strains from paddy fields in Louisiana (18). Conrad et al. isolated a Methanobacterium-like strain from Italian paddy fields (5). However, these strains have not been sufficiently characterized to be identified at the species level. To understand the ecology of methanogenic bacteria in paddy field soils, characterization and identification of methanogenic isolates from paddy field soils are necessary.

In this work, we isolated a methanogenic strain from a Japanese paddy field soil, characterized it, and identified it as a Methanobrevibacter arboriphilicus strain. Below we also discuss genomic relationships among Methanobrevibacter arboriphilicus strains.

\section{MATERIALS AND METHODS}

Source of inoculum and bacterial strains. The sampling site was the paddy field plot (gray lowland soil) with wheat straw incorporated at the Kyushu National Agricultural Experiment Station, Chikugo, Fukuoka, Japan. The soil sample was taken from the plow layer of flooded soil with a core sampler (volume, $100 \mathrm{ml}$; height, $5 \mathrm{~cm}$; diameter, $5 \mathrm{~cm}$ ) and was transported to a laboratory in a polyethylene bag filled with $\mathrm{N}_{2}$. The sampling date was 12 July 1989.

Methanobrevibacter arboriphilicus $\mathrm{DH} 1^{\mathrm{T}}\left(=\mathrm{DSM} 1125^{\mathrm{T}}\right)$ ( $\mathrm{T}=$ type strain), DC (= DSM 1536), and AZ (= DSM 744) and Methanobacterium thermoautotrophicum $\Delta \mathrm{H}^{\mathrm{T}}$ (= DSM $1053^{\mathrm{T}}$ ) were obtained from the Deutsche Sammlung von Mikroorganismen und Zellkulturen $\mathrm{GmbH}$, Braunschweig, Germany. Methanobrevibacter arboriphilicus A2 (= DSM 2462) was isolated from an anaerobic sewage digestor by

\footnotetext{
${ }^{*}$ Corresponding author.
}

Morii et al. (13). Escherichia coli K-12 (strain IAM 1264) was obtained from the Institute of Molecular and Cellular Biosciences (formerly Institute of Applied Microbiology), University of Tokyo, Tokyo, Japan.

Media and growth conditions. The basal medium used for enrichment and isolation of strain SA was a modification of LPBM (22), which contained (per liter of deionized water) $0.75 \mathrm{~g}$ of $\mathrm{KH}_{2} \mathrm{PO}_{4}, 0.75 \mathrm{~g}$ of $\mathrm{K}_{2} \mathrm{HPO}_{4}, 1.0 \mathrm{~g}$ of $\mathrm{NH}_{4} \mathrm{Cl}, 0.36$ $\mathrm{g}$ of $\mathrm{MgCl}_{2} \cdot 6 \mathrm{H}_{2} \mathrm{O}, 9 \mathrm{ml}$ of a trace mineral solution (13), 10 $\mathrm{ml}$ of a vitamin mixture solution (2), $0.5 \mathrm{ml}$ of a $0.2 \%$ resazurin solution, $0.5 \mathrm{~g}$ of $\mathrm{L}$-cysteine hydrochloride $\cdot \mathrm{H}_{2} \mathrm{O}$, $0.5 \mathrm{~g}$ of $\mathrm{Na}_{2} \mathrm{~S} \cdot 9 \mathrm{H}_{2} \mathrm{O}$, and $4.8 \mathrm{~g}$ of $\mathrm{NaHCO}_{3}$. For cultivation of Methanobrevibacter arboriphilicus strains, the basal medium was supplemented with $0.1 \%$ yeast extract (Difco). For roll tubes, we added $0.1 \%$ yeast extract (Difco), $0.1 \%$ Polypeptone (Daigo Eiyo Co., Osaka, Japan), and 1.7\% agar to the basal medium. The gas phase was $\mathrm{H}_{2}-\mathrm{CO}_{2}(4: 1)$ pressurized to $203 \mathrm{kPa}$, and the $\mathrm{pH}$ was 7.0 . Enrichment was performed in a 1-liter serum bottle sealed with a butyl rubber stopper and an aluminum seal containing $100 \mathrm{ml}$ of medium or in a $120-\mathrm{ml}$ serum bottle containing $5 \mathrm{ml}$ of medium. Mass cultures were grown at $37^{\circ} \mathrm{C}$ in a 15 -liter fermentor containing 5 liters of medium with sparging with $\mathrm{H}_{2}-\mathrm{CO}_{2}$ (4:1) (12). Methanobacterium thermoautotrophicum $\Delta \mathrm{H}^{\mathrm{T}}$ was cultivated as described previously (12).

To assess culture purity, we used the following media: the basal medium without $\mathrm{NaHCO}_{3}$ but containing $0.1 \%$ yeast extract (Difco), $0.1 \%$ Polypeptone (Daigo Eiyo), and 1\% glucose; VL medium (8) (10 g of Bacto Peptone [Difco], $5 \mathrm{~g}$ of yeast extract [Difco], $2 \mathrm{~g}$ of beef extract [Difco], $5 \mathrm{~g}$ of $\mathrm{NaCl}, 2 \mathrm{~g}$ of glucose, $1 \mathrm{mg}$ of resazurin sodium salt, $0.5 \mathrm{~g}$ of L-cysteine hydrochloride $\cdot \mathrm{H}_{2} \mathrm{O}, 0.5 \mathrm{~g}$ of $\mathrm{Na}_{2} \mathrm{~S} \cdot 9 \mathrm{H}_{2} \mathrm{O}, 1$ liter of distilled water; $\mathrm{pH} 7.0$ to 7.2); and the medium for sulfate reducers (8) $\left(0.5 \mathrm{~g}\right.$ of $\mathrm{K}_{2} \mathrm{HPO}_{4}, 1 \mathrm{~g}$ of yeast extract [Difco], 1 $\mathrm{g}$ of $\mathrm{NH}_{4} \mathrm{Cl}, 4.5 \mathrm{~g}$ of $\mathrm{Na}_{2} \mathrm{SO}_{4}, 0.06 \mathrm{~g}$ of $\mathrm{CaCl}_{2} \cdot 6 \mathrm{H}_{2} \mathrm{O}, 0.004$ $\mathrm{g}$ of $\mathrm{FeSO}_{4} \cdot 7 \mathrm{H}_{2} \mathrm{O}, 0.06 \mathrm{~g}$ of $\mathrm{MgSO}_{4} \cdot 7 \mathrm{H}_{2} \mathrm{O}, 5.0 \mathrm{~g}$ of sodium citrate $\cdot 2 \mathrm{H}_{2} \mathrm{O}, 0.1 \mathrm{~g}$ of sodium thioglycolate, $0.1 \mathrm{~g}$ of 
L-ascorbic acid, $1 \mathrm{mg}$ of resazurin sodium salt, $0.5 \mathrm{~g}$ of L-cysteine hydrochloride $\cdot \mathrm{H}_{2} \mathrm{O}, 0.5 \mathrm{~g}$ of $\mathrm{Na}_{2} \mathrm{~S} \cdot 9 \mathrm{H}_{2} \mathrm{O}, 1$ liter of distilled water; $\mathrm{pH} 7.1$ to 7.4). The media were prepared anoxically, and the gas phase was $\mathrm{N}_{2}$.

Effect of temperature and $\mathbf{p H}$ on growth. Cultures were grown in $50 \mathrm{ml}$ of the basal medium in 1-liter serum bottles. The $A_{660}$ values of cultures were measured to determine the effect of temperature on growth. To determine the effect of $\mathrm{pH}$ on growth, we measured the $A_{660}$ of cultures and $\mathrm{CH}_{4}$ production. Media with different $\mathrm{pH}$ values were prepared by varying the ratio of $\mathrm{H}_{2}-\mathrm{CO}_{2}$ mixture and the concentration of $\mathrm{NaHCO}_{3}$ or $\mathrm{Na}_{2} \mathrm{CO}_{3}$. The serum bottles were repeatedly repressurized to $203 \mathrm{kPa}$ with the original ratios of the $\mathrm{H}_{2}-\mathrm{CO}_{2}$ mixture, and $\mathrm{pH}$ values were checked during growth. The temperature was kept at $37^{\circ} \mathrm{C}$.

Methane production was determined with a Shimadzu model GC-6AM gas-liquid chromatograph equipped with a flame ionization detector and a stainless steel column $(3.0$ $\mathrm{mm}$ [inside diameter] by $2.0 \mathrm{~m}$ ) packed with Unibeads A (Gasukuro Kogyo, Inc., Tokyo, Japan). The column was kept at $70^{\circ} \mathrm{C}$.

Electron microscopy. Cells grown in the basal medium for 5 days at $37^{\circ} \mathrm{C}$ were stained negatively with $2 \%$ phosphotungstic acid and observed with a Hitachi model H-7000 electron microscope.

Lipid analysis. Cells of strain SA were harvested at the exponential phase and washed once with deionized water. The total lipids were extracted by the method of Bligh and Dyer as modified by Nishihara and Koga (15) from frozen and thawed cells (14). The two-dimensional thin-layer chromatographic pattern of the total lipids was examined as described previously (9). The total lipids of Methanobacterium thermoautotrophicum $\Delta \mathrm{H}^{\mathrm{T}}$ were used as a reference. The compositions of the hydrocarbon chains of the lipids were determined by gas-liquid chromatography of alkyl chlorides (17) prepared by $\mathrm{BCl}_{3}$ treatment (16). Gas-liquid chromatography was done with a glass column $(3.0 \mathrm{~mm}$ [inside diameter] by $2 \mathrm{~m}$ ) packed with $\mathrm{OV}-11$ at a temperature that was increased from 120 to $340^{\circ} \mathrm{C}$ at a rate of $20^{\circ} \mathrm{C} / \mathrm{min}$.

G+C content and DNA-DNA hybridization. Cells of methanogenic strains were harvested at the exponential phase. The harvested cells were washed with deionized water and saline-EDTA buffer (0.15 M NaCl, 0.1 M EDTA; pH 8.0) and were stored at $-20^{\circ} \mathrm{C}$ until they were used. Frozen cells were disrupted by freeze-pressing with an X-press (Biox Co., Nacka, Sweden). DNA was isolated and purified by the method of Marmur (10). Cells of $E$. coli were harvested from nutrient agar (Kyokuto, Tokyo, Japan) plates and washed with saline-EDTA. Frozen and thawed cells were used for isolation and purification of DNA by the method of Marmur (10).

The $\mathrm{G}+\mathrm{C}$ content of the DNA was determined by highperformance liquid chromatography (HPLC) (20). DNA from $E$. coli IAM $1264(\mathrm{G}+\mathrm{C}$ content, $51.6 \mathrm{~mol} \%)$ was used as the reference DNA. HPLC was carried out with a Waters model 6000A apparatus and a type 5C18-AR column (Nacalai Tesque, Inc., Kyoto, Japan) eluted with a mixture containing $0.2 \mathrm{M} \mathrm{NH}_{4} \mathrm{H}_{2} \mathrm{PO}_{4}$ and acetonitrile $(20: 1$, vol/vol) at a rate of $1 \mathrm{ml} / \mathrm{min}$ and monitored with a UV detector (model UVIDEC-100-II; JASCO) at $265 \mathrm{~nm}$.

DNA-DNA hybridization was performed by the membrane filter method (1). Each mixture of labeled and unlabeled DNAs was incubated at $60^{\circ} \mathrm{C}$ for $40 \mathrm{~h}$.

Serological test. The indirect immunofluorescence reaction of strain SA with the anti-A2 S-probe prepared by Morii et

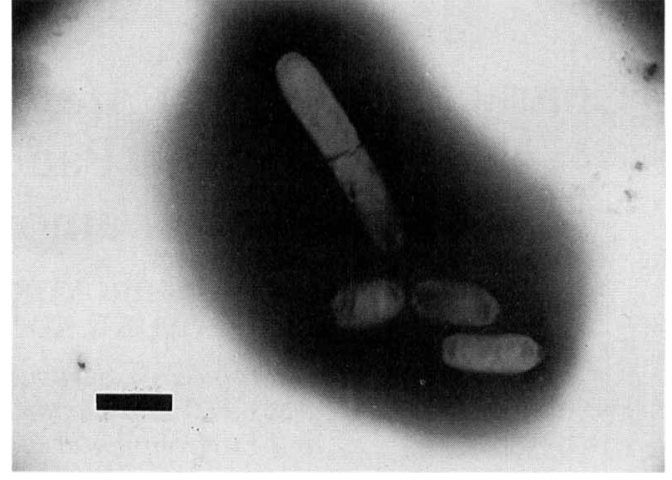

FIG. 1. Electron micrograph of negatively stained cells of strain SA. Bar $=1 \mu \mathrm{m}$.

al. (13) was determined by the method described by Conway de Macario et al. (6).

\section{RESULTS AND DISCUSSION}

Enrichment and isolation. A moist soil sample (about $40 \mathrm{~g}$ ) was inoculated into $100 \mathrm{ml}$ of the basal medium in a 1-liter serum bottle. The bottle was incubated with shaking at $30^{\circ} \mathrm{C}$. About $80 \%$ (vol/vol) of the culture was replaced weekly by fresh medium. Bekanamycin sulfate, sodium ampicillin, and lincomycin hydrochloride (each at $20 \mu \mathrm{g} / \mathrm{ml}$ ) were added to the seventh and eighth cultures. Serial dilutions of the eighth culture were inoculated into agar medium containing the antibiotics mentioned above, and roll tubes were prepared. The colonies that formed were inoculated into basal medium without antibiotics. After eight successive transfers, roll tubes were again prepared by using the agar medium without antibiotics. Well-isolated colonies were picked and inoculated into the basal medium. One of the cultures was used for ensuring purity. The culture was inoculated into three media without methanogenic substrates (see Materials and Methods), and the preparations were incubated statically for 55 days at $30^{\circ} \mathrm{C}$. No growth was observed, and no contaminants were detected microscopically. The pure culture was designated strain SA.

Morphology. Strain SA cells were short rods that were 0.7 $\mu \mathrm{m}$ wide by $2.1 \mu \mathrm{m}$ long (Fig. 1). The cells stained gram positive and were nonmotile. No flagella were observed. Sodium dodecyl sulfate and hypotonic conditions did not lyse cells when the method described by Boone and Whitman (3) was used.

Surface colonies on agar medium in roll tubes were 1.5 to $3.0 \mathrm{~mm}$ in diameter, round, entire to roughly entire, convex, and beige to ocher yellow. Cells grown in liquid culture with shaking tended to clump together.

Physiology. Strain SA grew on $\mathrm{H}_{2}-\mathrm{CO}_{2}$, and it was also able to utilize formate in F-complex medium (13). It could not use methanol, trimethylamine, and acetate as substrates. Vitamins were required for growth, but acetate and cysteine were not. It has been reported that the species of the genus Methanobrevibacter require vitamins for growth. Methanobrevibacter ruminantium and Methanobrevibacter smithil also require acetate, but Methanobrevibacter arboriphilicus does not (11). Yeast extract and Polypeptone stimulated cell growth of strain SA.

The generation time was $24 \mathrm{~h}$ (specific growth rate, 0.03 $\mathbf{h}^{-1}$ ) in 5 liters of the basal medium in a 15-liter fermentor with sparging with $\mathrm{H}_{2}-\mathrm{CO}_{2}(4: 1)$ at $37^{\circ} \mathrm{C}$. 


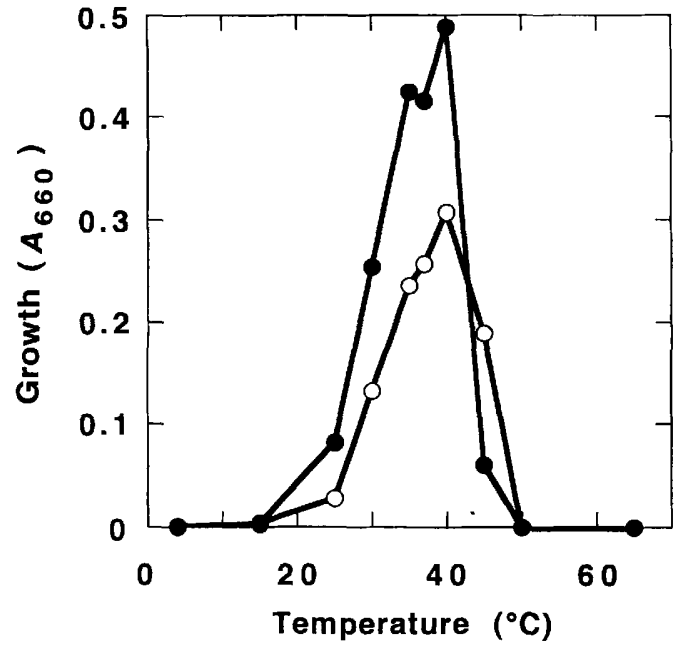

FIG. 2. Effect of temperature on growth of strain SA. Symbols: $\bigcirc, A_{660}$ after $65 \mathrm{~h}$ of incubation; $\odot, A_{660}$ after $97.5 \mathrm{~h}$ of incubation.

Figure 2 shows the effect of temperature on growth. Strain SA grew at 25 to $45^{\circ} \mathrm{C}$ but not at temperatures above $50^{\circ} \mathrm{C}$ or below $15^{\circ} \mathrm{C}$. The growth was fastest at 35 to $40^{\circ} \mathrm{C}$. Figure 3 shows the effect of $\mathrm{pH}$ on growth and methane production. The $\mathrm{pH}$ values did not change during growth. The strain grew at $\mathrm{pH} 6.0$ to 9.0. Growth was fastest and methane was produced most rapidly at $\mathrm{pH} 6.0$ to 7.5 . Good growth was observed in basal media containing 0 to $0.1 \mathrm{M} \mathrm{NaCl}$.

Lipids. The tetraether type of lipids was predominant $(68$ mol\%) in the cells of strain SA. Morii et al. (14) reported that the proportion of tetraether lipids in Methanobrevibacter arboriphilicus A2 cells was $81 \mathrm{~mol} \%$. The thin-layer chromatographic pattern of the polar lipids of strain SA was very similar to that of Methanobrevibacter arboriphilicus A2 (14). In particular, lipids which had mobilities similar to those of gentiobiosyl caldarchaetidylinositol, archaetidylserine, and caldarchaetidylserine were found on the thin-layer chromatography plates. These lipids are characteristic of the polar lipids of species in the family Methanobacteriaceae (9). Aminophospholipids which had mobilities similar to those of archaetidylethanolamine and caldarchaetidylethanolamine were not detected. These lipids are found in Methanobacterium species but not in Methanobrevibacter species (9). These results strongly suggested that strain SA belongs to the genus Methanobrevibacter.

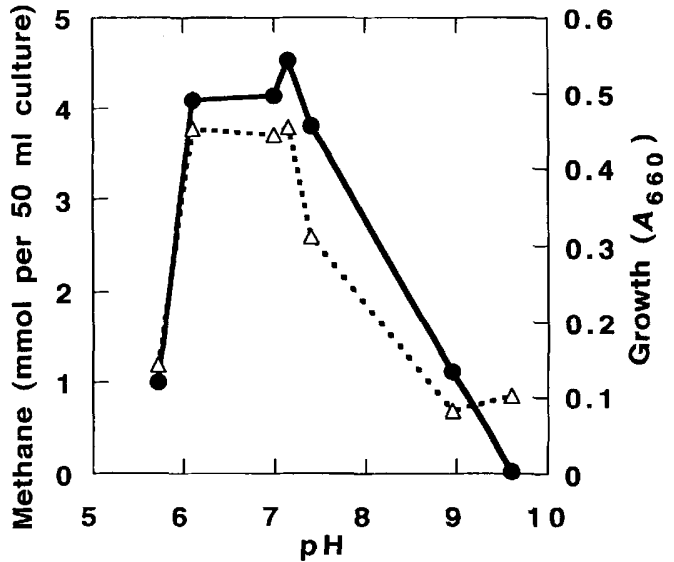

FIG. 3. Effect of $\mathrm{pH}$ on growth $(\triangle)$ and methane production $(\bullet)$ of strain SA after $90 \mathrm{~h}$ of incubation.

$G+C$ content and DNA-DNA hybridization. The $G+C$ contents of DNAs from strain SA and Methanobrevibacter arboriphilicus strains were 25.5 to $26.5 \mathrm{~mol} \%$ (Table 1). These values are somewhat lower than the values determined by the buoyant density method for strains $\mathrm{DH1}^{\mathrm{T}}(27.5$ $\mathrm{mol} \%$ ) (23), A2 (29.6 mol\%) (13), DC (27.7 mol\%), and AZ (31.6 mol\%) (2). A possible slight deviation from the linear equation in the very-low- $\mathrm{G}+\mathrm{C}$-content region between buoyant density and $\mathrm{G}+\mathrm{C}$ content described by Schildkraut et al. (19) may be the cause of the difference.

Strain SA exhibited DNA-DNA hybridization values of more than $70 \%$ with Methanobrevibacter arboriphilicus $\mathrm{DH}^{\mathrm{T}}$ (Table 1). From this result and other characteristics described above, strain SA was identified as a Methanobrevibacter arboriphilicus strain. This is, to our knowledge, the first strain which was isolated from a paddy field soil and identified to the species level. Further investigation of the population of this species in paddy field soil will be required. Strain SA is similar to A2 in formate utilization, while type strain DH1 and two other strains, strains DC and AZ, do not utilize formate (11). The indirect immunofluorescence reaction of strain SA with the anti-A2 S-probe was 3+. However, strain SA is different from strain $\mathrm{A} 2$ in its optimum $\mathrm{pH}$ and has a tendency to clump in liquid culture.

Strains $\mathrm{SA}, \mathrm{DH}^{\mathrm{T}}, \mathrm{A} 2$, and $\mathrm{DC}$ exhibited hybridization values of more than $60 \%$ with each other (Table 1 ), which is consistent with assignment of these four strains to the

TABLE 1. G+C contents of DNAs and levels of DNA-DNA hybridization among Methanobrevibacter arboriphilicus strains and other strains

\begin{tabular}{|c|c|c|c|c|c|c|}
\hline \multirow[b]{2}{*}{ Strain } & \multirow{2}{*}{$\begin{array}{c}\mathrm{G}+\mathrm{C} \text { content } \\
(\mathrm{mol} \%)\end{array}$} & \multicolumn{5}{|c|}{$\%$ Hybridization with labeled DNA from: } \\
\hline & & $\begin{array}{c}\text { Strain } \\
\text { SA }\end{array}$ & $\begin{array}{l}\text { Strain } \\
\mathrm{DH} 1^{\mathrm{T}}\end{array}$ & $\begin{array}{c}\text { Strain } \\
\text { A2 }\end{array}$ & $\begin{array}{c}\text { Strain } \\
\text { DC }\end{array}$ & $\begin{array}{c}\text { Strain } \\
\mathrm{AZ}\end{array}$ \\
\hline SA & $26.4 \pm 0.17^{a}$ & 100 & 72.7 & 108 & 79.4 & 36.5 \\
\hline Methanobrevibacter arboriphilicus $\mathrm{DH}^{\mathrm{T}}$ & $25.8 \pm 0.58^{a}$ & 75.6 & 100 & 76.0 & 66.1 & 39.4 \\
\hline Methanobrevibacter arboriphilicus A2 & $25.9 \pm 0.21^{a}$ & 87.7 & 59.9 & 100 & 79.6 & 35.3 \\
\hline Methanobrevibacter arboriphilicus DC & $26.2 \pm 0.13^{a}$ & 91.8 & 73.7 & 86.1 & 100 & 42.4 \\
\hline Methanobrevibacter arboriphilicus AZ & $25.5 \pm 0.25^{a}$ & 35.1 & 31.4 & 40.0 & 34.3 & 100 \\
\hline Methanobacterium thermoautotrophicum $\Delta \mathrm{H}^{\mathrm{T}}$ & $49.0 \pm 0.95^{b}$ & 1.6 & 1.2 & 2.6 & 1.8 & 2.0 \\
\hline E. coli $\mathrm{K}-12$ & $51.6^{c}$ & -0.0 & 0.0 & 0.2 & -0.0 & -0.0 \\
\hline
\end{tabular}

\footnotetext{
${ }^{a}$ Mean \pm standard deviation $(n=4)$.

${ }^{b}$ Mean \pm standard deviation $(n=2)$.

$c$ Data from reference 19 .
} 
species Methanobrevibacter arboriphilicus. On the other hand, strain AZ exhibited hybridization values of only 31 to $42 \%$ with these four strains of Methanobrevibacter arboriphilicus. The 16S rRNA oligonucleotide catalog of strain AZ has a similarity value of 0.84 with the $16 \mathrm{~S}$ rRNA oligonucleotide catalogs of strains $\mathrm{DH} 1^{\mathrm{T}}$ and $\mathrm{DC}$, although the similarity value between strains $\mathrm{DH} 1^{\mathrm{T}}$ and $\mathrm{DC}$ was 1.00 (2). On the basis of phylogenetic characteristics, strain AZ may be a member of a distinct species. However, we do not exclude strain AZ from Methanobrevibacter arboriphilicus because of the lack of differential phenotypic features. A few distinctive features of strain AZ (e.g., the presence of flagella [7] and a requirement for cysteine [21]) have been reported, but these are insufficient and inconclusive. Further information concerning the phenotypic characteristics of strain AZ and the other strains of Methanobrevibacter arboriphilicus will be required for taxonomic description of strain $\mathrm{AZ}$.

Methanobrevibacter arboriphilicus SA has been deposited in the Deutsche Sammlung von Mikroorganismen und Zellkulturen $\mathrm{GmbH}$, Braunschweig, Germany, as strain DSM 7056.

\section{ACKNOWLEDGMENTS}

We thank the following people: F. Tanaka (Kyushu National Agricultural Experiment Station) for supplying the soil sample; M. Ohga (University of Occupational and Environmental Health, Japan) for helpful advice concerning culture techniques for methanogens; T. Shiomi and T. Hayashi (Kyushu National Agricultural Experiment Station) for operation of the electron microscope; $M$. Nishihara (University of Occupational and Environmental Health, Japan) for the gas-liquid chromatography analysis; and S. Tanase (Kumamoto University) for cell disruption with the X-press apparatus.

\section{REFERENCES}

1. Akagawa-Matsushita, M., M. Matsuo, Y. Koga, and K. Yamasato. 1992. Alteromonas atlantica sp. nov. and Alteromonas carrageenovora sp. nov., bacteria that decompose algal polysaccharides. Int. J. Syst. Bacteriol. 42:621-627.

2. Balch, W. E., G. E. Fox, L. J. Magrum, C. R. Woese, and R. S. Wolfe. 1979. Methanogens: reevaluation of a unique biological group. Microbiol. Rev. 43:260-296.

3. Boone, D. R., and W. B. Whitman. 1988. Proposal of minimal standards for describing new taxa of methanogenic bacteria. Int. J. Syst. Bacteriol. 38:212-219.

4. Bouwman, A. F. 1989. The role of soils and land use in the greenhouse effect. Neth. J. Agric. Sci. 37:13-19.

5. Conrad, R., F. Bak, H. J. Seitz, B. Thebrath, H. P. Mayer, and H. Schütz. 1989. Hydrogen turnover by psychrotrophic homoacetogenic and mesophilic methanogenic bacteria in anoxic paddy soil and lake sediment. FEMS Microbiol. Ecol. 62:285-294.

6. Conway de Macario, E., A. J. L. Macario, and M. J. Wolin. 1982. Antigenic analysis of Methanomicrobiales and Methano- brevibacter arboriphilus. J. Bacteriol. 152:762-764.

7. Doddema, H. J., J. W. M. Derksen, and G. D. Vogels. 1979. Fimbriae and flagella of methanogenic bacteria. FEMS Microbiol. Lett. 5:135-138.

8. Japanese Society of Soil Microbiology. 1975. Experimental method in soil microbiology, p. 431-443. Yokendo, Tokyo. (In Japanese.)

9. Koga, Y., M. Ohga, M. Nishihara, and H. Morii. 1987. Distribution of a diphytanyl ether analog of phosphatidylserine and an ethanolamine-containing tetraether lipid in methanogenic bacteria. Syst. Appl. Microbiol. 9:176-182.

10. Marmur, J. 1961. A procedure for the isolation of deoxyribonucleic acid from micro-organisms. J. Mol. Biol. 3:208-218.

11. Miller, T. L. 1989. Genus II. Methanobrevibacter, p. 2178-2183. In J. T. Staley, M. P. Bryant, N. Pfennig, and J. G. Holt (ed.), Bergey's manual of systematic bacteriology, vol. 3. The Williams \& Wilkins Co., Baltimore.

12. Morii, H., and Y. Koga. 1992. An improved assay method for a pseudomurein-degrading enzyme of Methanobacterium wolfei and the protoplast formation of Methanobacterium thermoautotrophicum by the enzyme. J. Ferment. Bioeng. 73:6-10.

13. Morii, H., M. Nishihara, and Y. Koga. 1983. Isolation, characterization and physiology of a new formate-assimilable methanogenic strain (A2) of Methanobrevibacter arboriphilus. Agric. Biol. Chem. 47:2781-2789.

14. Morii, H., M. Nishihara, and Y. Koga. 1988. Composition of polar lipids of Methanobrevibacter arboriphilicus and structure determination of the signature phosphoglycolipid of Methanobacteriaceae. Agric. Biol. Chem. 52:3149-3156.

15. Nishihara, M., and Y. Koga. 1987. Extraction and composition of polar lipids from the archaebacterium, Methanobacterium thermoautotrophicum: effective extraction of tetraether lipids by an acidified solvent. J. Biochem. 101:997-1005.

16. Nishihara, M., and Y. Koga. 1988. Quantitative conversion of diether or tetraether phospholipids to glycerophosphoesters by dealkylation with boron trichloride: a tool for structural analysis of archaebacterial lipids. J. Lipid Res. 29:384-388.

17. Nishihara, M., H. Morii, and Y. Koga. 1987. Structure determination of a quartet of novel tetraether lipids from Methanobacterium thermoautotrophicum. J. Biochem. 101:1007-1015.

18. Rajagopal, B. S., N. Belay, and L. Daniels. 1988. Isolation and characterization of methanogenic bacteria from rice paddies. FEMS Microbiol. Ecol. 53:153-158.

19. Schildkraut, C. L., J. Marmur, and P. Doty. 1962. Determination of the base composition of deoxyribonucleic acid from its buoyant density in CsCl. J. Mol. Biol. 4:430-443.

20. Tamaoka, J., and K. Komagata. 1984. Determination of DNA base composition by reversed-phase high-performance liquid chromatography. FEMS Microbiol. Lett. 25:125-128.

21. Zehnder, A. J. B., and K. Wuhrmann. 1977. Physiology of a Methanobacterium strain AZ. Arch. Microbiol. 111:199-205.

22. Zeikus, J. G. 1977. The biology of methanogenic bacteria. Bacteriol. Rev. 41:514-541.

23. Zeikus, J. G., and D. L. Henning. 1975. Methanobacterium arbophilicum sp. nov. An obligate anaerobe isolated from wetwood of living trees. Antonie Leeuwenhoek 41:543-552. 